\title{
Histopathological and biochemical evidence of hepatopancreatic toxicity caused by cadmium and zinc in the white shrimp, Litopenaeus vannamei
}

\author{
Jui-Pin $\mathrm{Wu}^{\mathrm{a}, *}$, Hon-Cheng Chen ${ }^{\mathrm{b}}$, Da-Ji Huang ${ }^{\mathrm{c}}$ \\ a Division of Environmental Health and Occupational Medicine, National Health Research Institutes, No. 35 Keyan Road, Zhunan Town, Miaoli 350, Taiwan, ROC \\ ${ }^{\mathrm{b}}$ Institute of Fisheries Sciences, National Taiwan University, Taipei 106, Taiwan, ROC \\ ${ }^{\mathrm{c}}$ Department of Environmental Resources Management, Chia Nan University of Pharmacy and Science, Tainan 717, Taiwan, ROC
}

\section{A R T I C L E I N F O}

\section{Article history:}

Received 18 February 2008

Received in revised form 8 August 2008

Accepted 13 August 2008

Available online 21 September 2008

\section{Keywords:}

Litopenaeus vannamei

Cadmium

Zinc

Hepatopancreas

Histopathology

\begin{abstract}
A B S T R A C T
The white shrimp, Litopenaeus vannamei, a globally important cultured prawn species, is an ideal animal for studying the impairment caused by the effects of heavy metals that are often detected in coastal areas. In this study, L. vannamei was exposed to different concentrations of cadmium (Cd) and zinc ( $\mathrm{Zn}$ ) for up to $28 \mathrm{~d}$. Histopathological alterations in the hepatopancreas were observed in L. vannamei after long-term exposure to $\mathrm{Cd}$ and $\mathrm{Zn}$. Hepatopancreatic injury was further confirmed by the inductions of two biochemical markers, hemolymphatic glutamate-oxalacetate transaminase (GOT) and glutamate-pyruvate transaminase (GPT). It was notable that $L$. vannamei was able to repair its hepatopancreas from the damage caused by $\mathrm{Zn}$, which was evidenced by the results of the histopathological observations, determinations of tissue metal concentrations, and examination of GOT and GPT levels.
\end{abstract}

(c) 2008 Elsevier Ltd. All rights reserved.

\section{Introduction}

The hepatopancreas, being analogous to the liver and combining many of the functions of the liver, pancreas, and intestine of vertebrates, plays important roles in several metabolic processes in crustaceans (Caceci et al., 1988; Bhavan and Geraldine, 2000). Previous studies on the hepatopancreas at different biological levels such as the structure, development, physiology, metabolism, and biochemistry concluded that this digestive organ possesses several functions, including absorption, digestion, storage, and secretion (Dall and Moriarty, 1983; Caceci et al., 1988). In addition, several specific enzyme systems responsible for biotransformation, e.g., the cytochrome $\mathrm{p} 450$ system and glutathione $S$-transferase, as well as proteins such as metallothioneins appear in the hepatopancreas, so that this digestive organ also possesses the ability to biotransform, sequester, and detoxify many kinds of xenobiotics; some biotransformations, however, may in fact actually increase the toxicity of certain xenobiotics (Martinez et al., 1993; Pederson et al., 1997; James and Boyle, 1998; Snyder, 2000; Ahearn et al., 2004). Therefore, the hepatopancreas, or so-called mid-gut gland, is a very important organ for crustaceans, and topics related to it have consistently attracted the attention of many researchers.

Although the hepatopancreas is responsible for the major portion of detoxification activities in crustaceans when exposed to toxicants and pollutants, in aquatic crustaceans, its functions and structure are

\footnotetext{
* Corresponding author. Tel.: +886 37 246166x36505; fax: +886 37587406.

E-mail address: rb5_wu@nhri.org.tw (J.-P. Wu).
}

likely to be affected by certain xenobiotics, such as pesticides and aflatoxin (Lightner et al., 1982; Bautista et al., 1994; Bhavan and Geraldine, 2000). These materials have been reported and demonstrated to have hepatopancreatic toxicities, which resulted in histological alterations to the hepatopancreas of studied organisms. Surprisingly, there are relatively few related studies on heavy metals even though they are common pollutants. We previously reported that the heavy metals, cadmium ( $\mathrm{Cd}$ ) and zinc $(\mathrm{Zn})$, caused alterations and the unavailability of biochemical and nutritional materials within the hepatopancreas of the white shrimp, Litopenaeus vannamei; these changes might have been the cause of growth retardation we observed after exposure to these metals (Wu and Chen, 2005a). However, the effects of these metals on the histological structure of the hepatopancreas of this species have never been reported.

Therefore, the major objective of the present paper was to study histopathological alterations in the hepatopancreas of L. vannamei, a globally important cultured prawn species, after exposure to $\mathrm{Cd}$ and $\mathrm{Zn}$. Furthermore, the activities of two enzymes, glutamateoxalacetate transaminase (GOT) and glutamate-pyruvate transaminase (GPT), were also measured in this study to serve as biochemical evidence of damage to hepatopancreatic cells and tissues.

\section{Materials and methods}

\subsection{Animal maintenance}

Postlarval L. vannamei shrimp were obtained from a commercial shrimp hatchery in Pingtung, southern Taiwan and maintained in 
the laboratory for over 2 months until they reached the juvenile stage ( $2.15 \pm 0.18 \mathrm{~g} ; 9.83 \pm 0.59 \mathrm{~cm}$ long). Water conditions during shrimp rearing and the experimental period were a temperature of $25^{\circ} \mathrm{C}$, a salinity of 15 p.s.u., dissolved oxygen (DO) of 5.8$6.5 \mathrm{mg} \mathrm{L}^{-1}$, and a $\mathrm{pH}$ of 7.15-7.87, under a 12:12-h light-dark regime with continuous aeration and filtration.

\subsection{Histopathological studies of the hepatopancreas and determination of metal concentrations}

L. vannamei shrimp in the intermolt stage were exposed to Cd or $\mathrm{Zn}$ and then sacrificed for the histological study of the hepatopancreas. Animals were divided into seven groups, each of which contained 10 shrimp that were exposed to concentrations of either 0.1 , 0.2 , or $0.4 \mathrm{mg} \mathrm{Cd} \mathrm{L}^{-1}$ as $\mathrm{CdSO}_{4}$, or $0.05,0.2$, or $0.6 \mathrm{mg} \mathrm{Zn} \mathrm{L}^{-1}$ as $\mathrm{ZnSO}_{4}$, and one control group (with no exposure to either metal). Samples were taken after 7, 14, 21, and $28 \mathrm{~d}$ of exposure. The hepatopancreas samples were very carefully dissected out for both histopathological studies and determination of metal concentrations. For the histopathological studies, samples were fixed in $4 \%$ buffered formalin, embedded in paraffin, sectioned at an $8-\mu \mathrm{m}$ thickness on a microtone (Microm, HM330, Heidelberg, Germany), stained with hematoxylin and eosin (H\&E), and examined with an Olympus microscope (Tokyo, Japan). Metal concentrations in the hepatopancreas were determined by atomic absorption spectrophotometry as previously described (Wu and Chen, 2005b).

\subsection{Determination of GOT and GPT activities}

To examine the enzymatic activities of GOT and GPT, L. vannamei shrimp were exposed to concentrations of either $0.2 \mathrm{mg} \mathrm{Cd} \mathrm{L}^{-1}$ or $0.2 \mathrm{mg} \mathrm{Zn} \mathrm{L}{ }^{-1}$, in addition to the control set, with each treatment containing at least 15 shrimp in a 20 -L tank. Each treatment was repeated three times. Four to six shrimp in each treatment were randomly taken on days 7,14 , and 28 . In all cases, hemolymph was extracted by heart puncture using a $0.5-\mathrm{mL}$ syringe pre-rinsed with citrate-EDTA buffer $(0.45 \mathrm{M} \mathrm{NaCl}, 0.1 \mathrm{M}$ glucose, $30 \mathrm{mM}$ trisodium citrate, $26 \mathrm{mM}$ citric acid, and $10 \mathrm{mM}$ EDTA pH 4.6; precooled to $7{ }^{\circ} \mathrm{C}$ ), an anticoagulant used with marine invertebrates (Söderhäll and Smith, 1983). Each hemolymph sample was individually and immediately tested to determine the GOT and GPT activities using Merck GOT and GPT diagnostic kits (Cat. Nos. 1.14829.0001 and 1.14820.0001, respectively; Darmstadt, Germany) based on the rate of consumption of the reduced form of nicotinamide-adenine dinucleotide (NADH) that could be measured photometrically at $365 \mathrm{~nm}$. If necessary, a sample was diluted with $9 \mathrm{~g} \mathrm{~L}^{-1} \mathrm{NaCl}$ before detection as suggested in the kit instructions.

\subsection{Statistical analyses}

Statistical analysis was performed with $t$-test to determine the difference between results of treated and control animals, and a $p<0.05$ level was considered statistically significant.

\section{Results}

\subsection{Histological studies of the hepatopancreas of L. vannamei}

The hepatopancreas of control shrimp exhibited the well-organized glandular tubular structure normally seen in prawn species (Bell and Lightner, 1988; Caceci et al., 1988; Lightner et al., 1996; Bhavan and Geraldine, 2000). A longitudinal section of the apical region of a hepatopancreatic tubule showed that the cell surface facing the lumen was covered with a microvillous brush border, and the tubule apex contained undifferentiated embryonic (embryonalzellen) cells (E-cells; Fig. 1A). Moving away from the apex, the cells began to differentiate into developing absorptive, storage (restzellen) cells (R-cells). A transverse section of the middle-proximal region of the tubules showed that the tubules were empty of food material and appeared in a hexagonal arrangement or "star shape" in the lumen, and the basal lamina outlined each tubule (Fig. 1B). Also, in this section, different cell types could clearly be observed under a higher magnification (Fig. 1C). Developing R-cells are those in which the cytoplasm characteristically contains numerous vacuoles and lipid droplets, while fibrous (fibrillenzellen) cells (F-cells) are more basophilic, have larger nuclei than R-cells, and typically contain one prominent nucleoli. This region also contained the large distinctive secretory (blasenzellen) cells (B-cells), each of which contained one large apical secretory vacuole. Immediately surrounding each tubule was a network of myoepithelial cells with prominent nuclei and associated contractile fibers.

After exposure to $\mathrm{Cd}$, alterations to the hepatopancreatic tissue of treated L. vannamei were observed. In shrimp exposed to lower concentrations of 0.1 and $0.2 \mathrm{mg} \mathrm{Cd} \mathrm{L}^{-1}$, large numbers of vacuoles appeared in the tubular epithelial cells of the hepatopancreas of animals exposed to $0.2 \mathrm{mg} \mathrm{Cd} \mathrm{L}^{-1}$ for $28 \mathrm{~d}$, as well as one deeply affected individual exposed to $0.1 \mathrm{mg} \mathrm{Cd} \mathrm{L}^{-1}$ for $21 \mathrm{~d}$ (Fig. $2 \mathrm{~A}$ and $\mathrm{B}$ ). In addition, the star shape of the lumen was partially lost due to morphological changes of the tubular epithelial cells, because some cells decreased in height from a normal columnar height to a low cuboidal form. Also, a slight thickening of the basal lamina increased the distance between adjacent tubules in shrimp exposed to lower concentrations of $\mathrm{Cd}$. When $L$. vannamei was exposed to a higher concentration of $\mathrm{Cd}\left(0.4 \mathrm{mg} \mathrm{L}^{-1}\right)$, severe lesions in the hepatopancreas were very obvious. In shrimp exposed to $0.4 \mathrm{mg} \mathrm{Cd} \mathrm{L}^{-1}$ for $14 \mathrm{~d}$, tubular epithelial cells were heavily vacuolated and even ruptured (Figs. $2 \mathrm{C}$ and D). Thickening of the basal lamina and a decrease in cell height were also conspicuous with this treatment. Cellular hypertrophy and vacuolization resulting in a scraggy lumen surface were obvious, when the section was examined longitudinally in comparison to the hepatopancreas of normal animals (Fig. 2E). Furthermore, after exposure for $21 \mathrm{~d}$, the arrangement of the tubules and shape of the lumens had substantially been altered (Fig. 2F). Infiltration of hemocytes began in the intertubular hemocoel between the middle-proximal portions of the hepatopancreas tubules. Generally, the distance between adjacent tubules was longer than that of normal shrimp. Atrophy and necrosis of tubules were conspicuous. Necrotic tubules of the hepatopancreas were rounded off and began to slough off their basement membrane (Fig. 2G). In this study, no shrimp survived after exposure to $0.4 \mathrm{mg} \mathrm{Cd} \mathrm{L}^{-1}$ for $28 \mathrm{~d}$, and thus no histological results from this treatment are available.

Similarly, exposure to $\mathrm{Zn}$ caused some histological effects on the hepatopancreas of $L$. vannamei, especially those exposed to 0.2 and $0.6 \mathrm{mg} \mathrm{Zn} \mathrm{L}^{-1}$. Histological differences between the hepatopancreas of $0.2 \mathrm{mg} \mathrm{Zn} \mathrm{L}^{-1}$-treated shrimp and normal ones included vacuolization resulting in hypertrophy in a large number of tubular epithelial cells and an increase in the distance between adjacent tubules, probably due to detachment of tubules from their basement membrane ( Fig. $3 \mathrm{~A}$ and B). It is very interesting that symptoms of treated shrimps exposed to $0.2 \mathrm{mg} \mathrm{Zn} \mathrm{L}^{-1}$ for both 14 and $28 \mathrm{~d}$ were almost the same, and showed no time-dependence with these two treatments. In other words, the hepatopancreas of shrimp exposed to $0.2 \mathrm{mg} \mathrm{Zn} \mathrm{L}{ }^{-1}$ for $28 \mathrm{~d}$ showed no more-serious or -substantial alterations than those individuals exposed to the same concentration of $\mathrm{Zn}$ for $14 \mathrm{~d}$. However, when shrimp were exposed to a higher concentration of $\mathrm{Zn}\left(0.6 \mathrm{mg} \mathrm{Zn} \mathrm{L}^{-1}\right)$, different alterations were apparent 


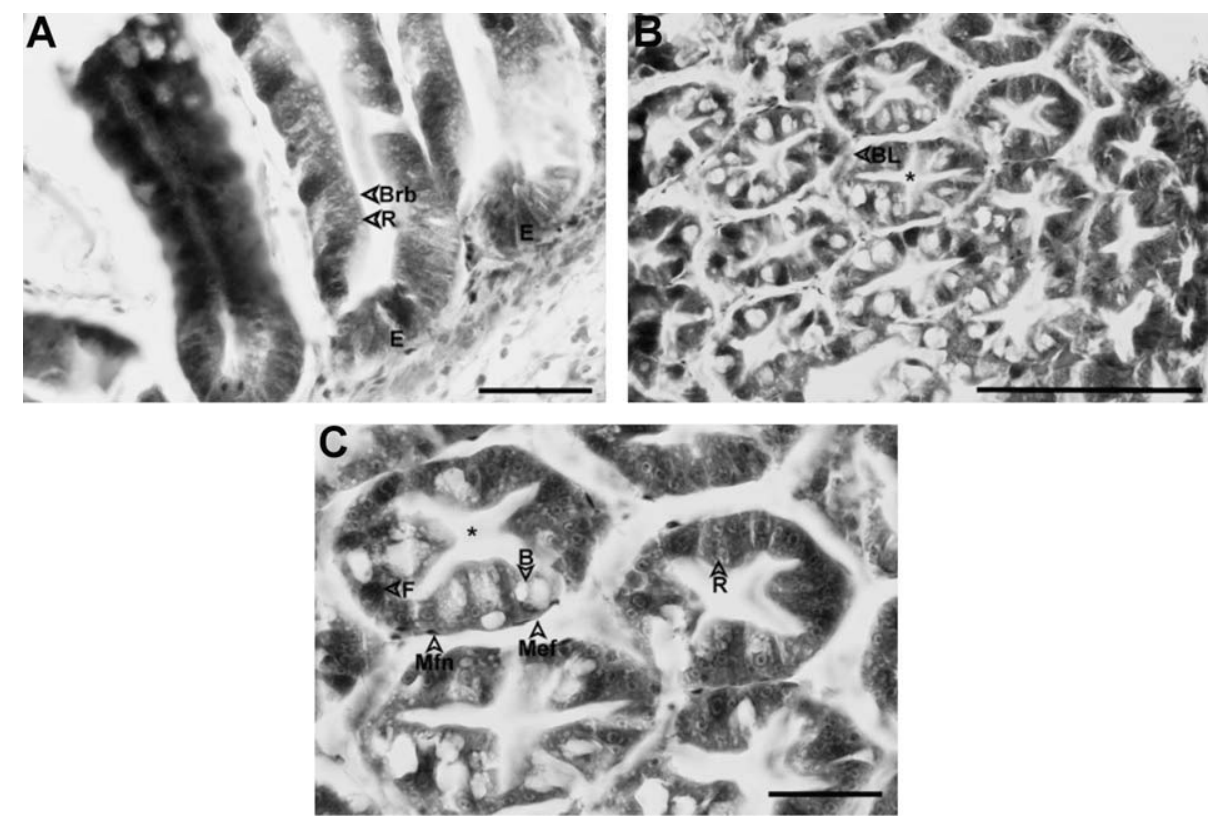

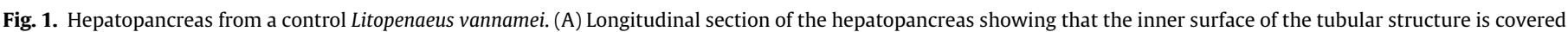

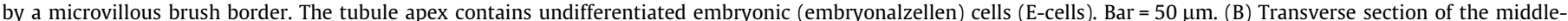

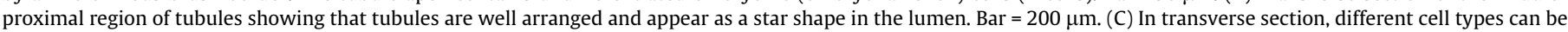

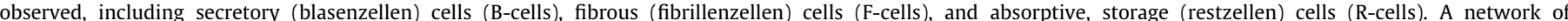

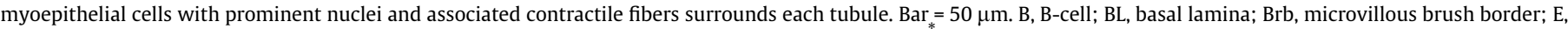
E-cell; F, F-cell; Mef, myoepithelial fibers; Mfn, myoepithelial cells with prominent nuclei; R, R-cell; ${ }^{*}$, star shape of the lumen.

in shrimp at different exposure times. In the hepatopancreatic tubular systems of shrimp exposed to $0.6 \mathrm{mg} \mathrm{Zn} \mathrm{L}^{-1}$ for 14 and $21 \mathrm{~d}$, slight to moderate vacuolization was apparent in tubular epithelial cells (Fig. 3C and D). In some regions of the hepatopancreatic tubules from shrimp exposed to $0.6 \mathrm{mg} \mathrm{Zn} \mathrm{L}^{-1}$ for $21 \mathrm{~d}$, a decrease in the epithelial cell height, cell rupture, and formation of an abnormal lumen shape were observed (Fig. 3E and F). The most impressive symptoms appeared in the section from shrimp exposed to $0.6 \mathrm{mg} \mathrm{Zn} \mathrm{L}^{-1}$ for $28 \mathrm{~d}$ (Fig. $3 \mathrm{G}$ and I). Tubular epithelial cells had detached from the basal lamina. The tubules were seriously atrophied, and some epithelial cells were hypertrophied and vacuolated, so that the tubules looked like they were compressed and the lumen-facing surface was oppilated and irregular (Fig. 3H). Furthermore, melanization was observed in the epithelial cells, especially in the periphery of the tubules (Fig. 3I).

No obvious alterations were observed by light microscopy of the hepatopancreatic tissue of treated $L$. vannamei after exposure to $0.1 \mathrm{mg} \mathrm{Cd} \mathrm{L}^{-1}$ for 14 or $21 \mathrm{~d}, 0.2 \mathrm{mg} \mathrm{Cd} \mathrm{L}^{-1}$ for 14 or $21 \mathrm{~d}$, or $0.05 \mathrm{mg} \mathrm{Zn} \mathrm{L}^{-1}$ for 14,21 , or $28 \mathrm{~d}$ in this study, except for one deeply affected individual exposed to $0.1 \mathrm{mg} \mathrm{Cd} \mathrm{L}^{-1}$ for $21 \mathrm{~d}$, which was moribund when sampled.

\subsection{Metal concentrations in the hepatopancreas of $L$. vannamei}

Metal concentrations accumulating in the hepatopancreas of $L$. vannamei were determined (Tables 1 and 2). The hepatopancreatic Cd concentrations were undetectable in control animals at each sampling time (Table 1). After exposure to $0.1 \mathrm{mg} \mathrm{Cd} \mathrm{L}^{-1}$, however, the hepatopancreatic Cd concentration was $0.07 \pm 0.03 \mathrm{mg} \mathrm{g}^{-1}$ after $7 \mathrm{~d}$ of exposure and significantly increased to $0.19 \pm 0.0 .08$, $0.24 \pm 0.06$ and $0.33 \pm 0.08 \mathrm{mg} \mathrm{g}^{-1}$ after 14,21 and $28 \mathrm{~d}$, respectively. A similar increasing trend was also observed in $0.2 \mathrm{mg}$ $\mathrm{Cd} \mathrm{L}^{-1}$-treated animals, and the hepatopancreatic Cd concentrations were $0.18 \pm 0.09,0.37 \pm 0.07,0.38 \pm 0.05$, and $0.52 \pm 0.18$ $\mathrm{mg} \mathrm{g}^{-1}$, respectively, after $7,14,21$, and $28 \mathrm{~d}$ of exposure.
The hepatopancreatic zinc concentration in control shrimp was $0.19 \pm 0.04 \mathrm{mg} \mathrm{g}^{-1}$ (Table 2). No significant difference was apparent in hepatopancreatic zinc concentrations of $0.05 \mathrm{mg} \mathrm{Zn} \mathrm{L}^{-1}$ treated animals compared to the control. In the $0.2 \mathrm{mg} \mathrm{Zn} \mathrm{L}^{-1}$ treatment, the hepatopancreatic zinc concentration significantly increased to $0.31 \pm 0.04$ and $0.34 \pm 0.06 \mathrm{mg} \mathrm{g}^{-1} \quad(p<0.05)$ after exposure for 7 and $14 \mathrm{~d}$, but then declined to levels that showed no significant difference compared to those of the control after exposure for 21 and $28 \mathrm{~d}$.

\subsection{Effects of $C d$ and $Z n$ on hemolymphatic GOT and GPT activities of $L$. vannamei}

According to the results of the enzyme activity determinations, hemolymphatic GOT and GPT activities of control L. vannamei were $19.8 \pm 4.4$ and $14.7 \pm 4.9 \mathrm{U} \mathrm{L}^{-1}$, respectively. Exposure of $L$. vannamei to $\mathrm{Cd}$ for $28 \mathrm{~d}$ resulted in increased hemolymphatic GOT and GPT activities, according to our observations (Table 1 ). After exposure for 7, 14, and $28 \mathrm{~d}$, the average levels of GOT activities of Cdtreated L. vannamei were $180.3 \%, 264.4 \%$, and $218.7 \%$ higher compared to the average level of the control animals. Similarly, the average levels of GPT activities of individuals exposed to $\mathrm{Cd}$ for 7 , 14 , and $28 \mathrm{~d}$ were $352.4 \%, 337.1 \%$, and $381.0 \%$ higher, respectively. Although both hemolymphatic GOT and GPT activities also increased after shrimp were exposed to $\mathrm{Zn}$ for $7 \mathrm{~d}$ and were $361.4 \%$ and $521.4 \%$ higher than those of control individuals, declines in both enzyme activities were observed and no significant differences were evident from those of the control group after exposure for 14 and $28 \mathrm{~d}$ (Table 2).

\section{Discussion}

The liver and hepatopancreas are known to be very sensitive to different diets and water-borne pollutants; thus these organs are often used to monitor the effects of various toxicants (Bautista et al., 1994). The hepatopancreas is essentially composed 

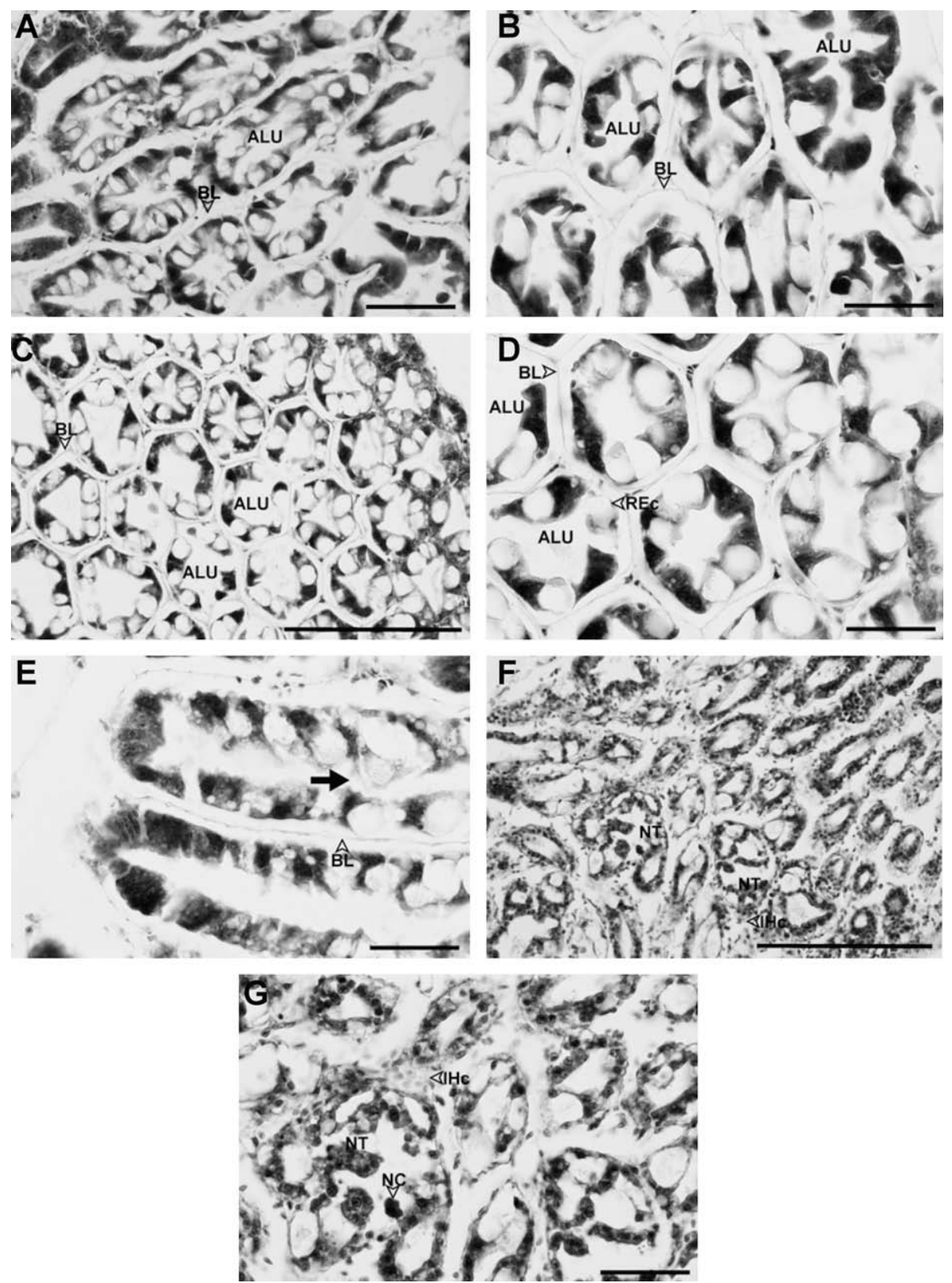

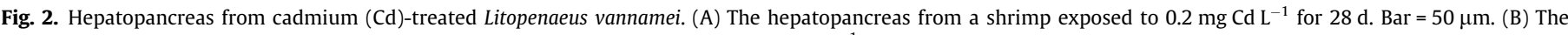

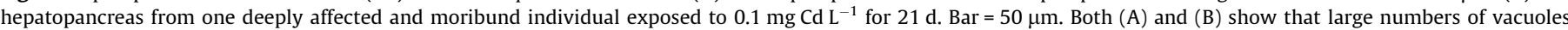

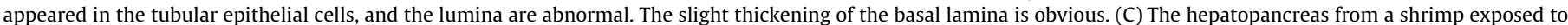

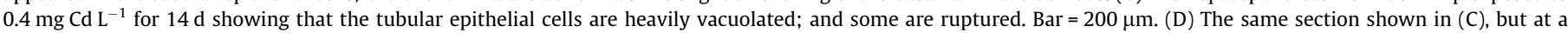

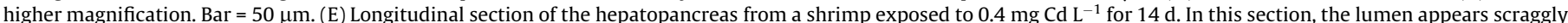

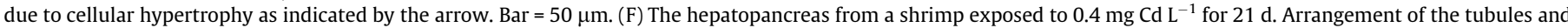

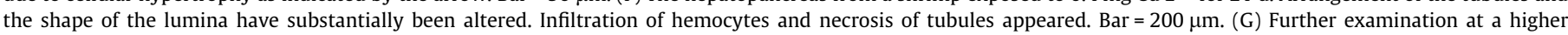

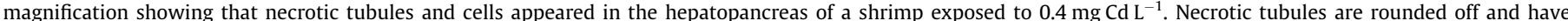

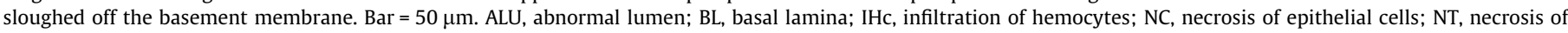
tubules; REc, ruptured epithelial cells.

of branched tubules and different types of epithelial cells lining the tubules. Therefore, it is likely that exposure to noxious chemicals or xenobiotics would be reflected in alterations to the structures of tubules and epithelial cells (Bhavan and Geraldine, 2000). The effects of exposure to various toxicants on histological and cellular changes to the liver and hepatopancreas of several aquatic organisms have been investigated (Lightner et al., 1982; Doughtie and Rao, 1984; Förlin et al., 1986; Khangarot, 1992; Bautista, 1994; Lightner et al., 1996; Bhavan and Geraldine, 2000). The effects on the hepatopancreas of several prawn species of aflatoxin, naturally produced by the fungi, Aspergillus flavus and Aspergillus parasiticus, have been studied (Lightner et al., 1982; Bautista, 1994), and it is thought to possess toxicity to the liver of higher organisms. Aflatoxin-induced structural changes in the hepatopancreas of prawns included a decrease in the cellular height of the tubular epithelium, a reduction in the abundance of secretory and lipid vacuoles, infiltration of hemocytes, atrophy of epithelial cells, development of pyknotic nuclei, cytolysis, the formation of fibrosis, and the melanized encapsulation of necrotic tissues. Likewise, similar studies have 

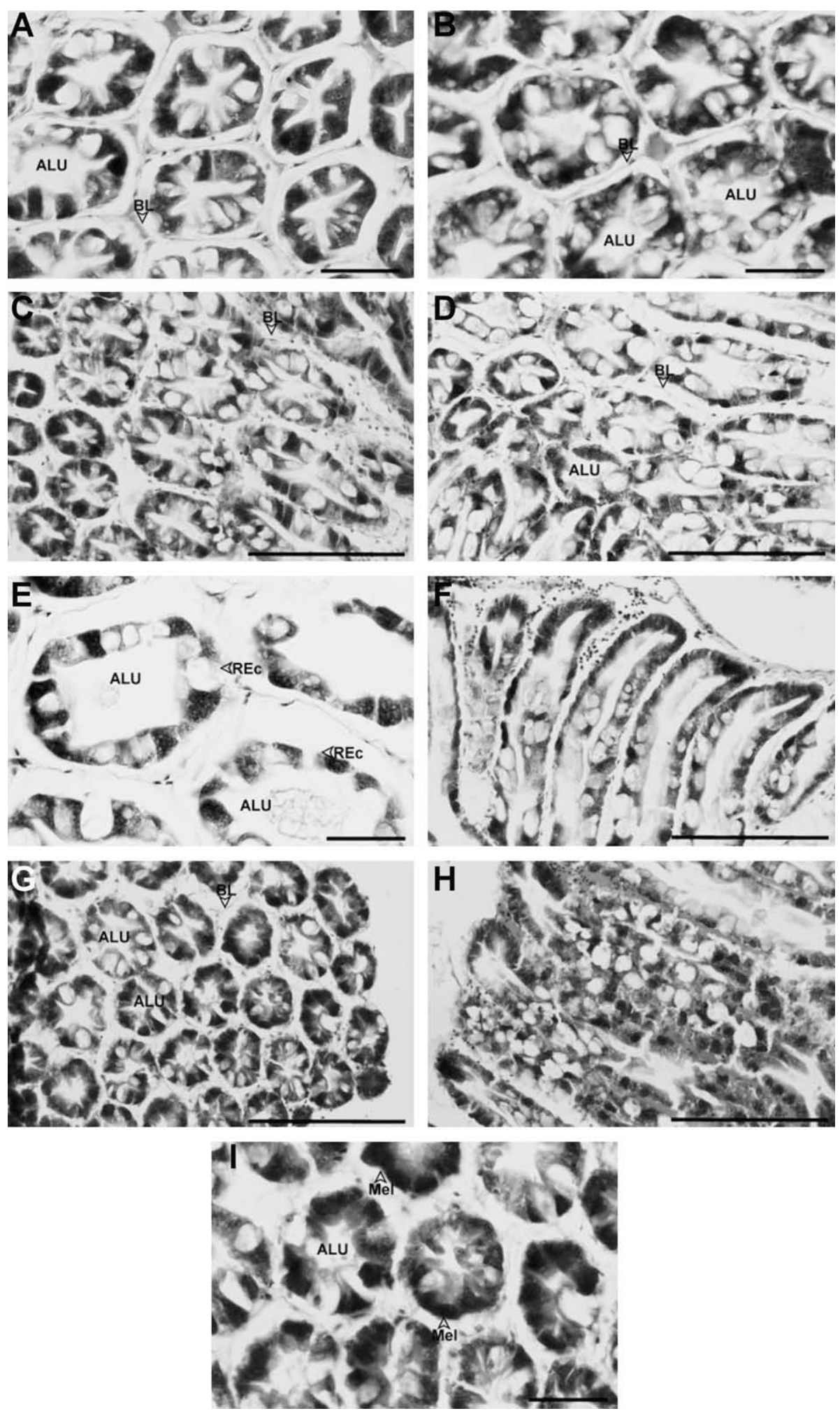

Fig. 3. Hepatopancreas from zinc (Zn)-treated Litopenaeus vannamei. (A) The hepatopancreas from a shrimp exposed to $0.2 \mathrm{mg} \mathrm{Zn} \mathrm{L}^{-1}$ for $14 \mathrm{~d}$. Bar $=50 \mu \mathrm{m}$. (B) The hepatopancreas from a shrimp exposed to $0.2 \mathrm{mg} \mathrm{Zn} \mathrm{L}^{-1}$ for $28 \mathrm{~d}$. Bar $=50 \mu \mathrm{m}$. Both $(\mathrm{A})$ and $(\mathrm{B})$ show that large numbers of vacuoles appeared in the tubular epithelial cells, and the lumens are abnormal. (C) The hepatopancreas from a shrimp exposed to $0.6 \mathrm{mg} \mathrm{Zn} \mathrm{L}^{-1}$ for $14 \mathrm{~d}$. Bar $=200 \mu \mathrm{m}$. (D) The hepatopancreas from a shrimp exposed to $0.6 \mathrm{mg} \mathrm{Zn} \mathrm{L}^{-1}$ for $21 \mathrm{~d}$. Bar $=200 \mu \mathrm{m}$. In sections shown in (C) and (D), slight to moderate vacuolization of the tubular epithelial cells is apparent. (E) The hepatopancreas from a shrimp exposed to $0.6 \mathrm{mg} \mathrm{Zn} \mathrm{L}^{-1}$ for $21 \mathrm{~d}$. In this section, a decrease in epithelial cell height as well as cell rupture resulting in the formation of an abnormal lumen are clearly evident. Bar $=50 \mu \mathrm{m}$. (F) A longitudinal section of the hepatopancreas from a shrimp exposed to $0.6 \mathrm{mg} \mathrm{Zn} \mathrm{L}^{-1}$ for $21 \mathrm{~d}$. Note that the lumen of the tubules is abnormal

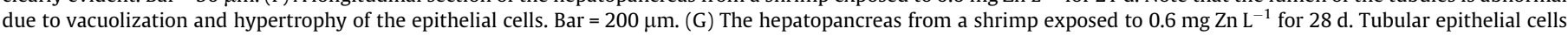
have detached from the basal lamina with this treatment, and the tubules have atrophied. Bar $=200 \mu \mathrm{m}$. (H) A longitudinal section of the hepatopancreas from a shrimp exposed to $0.6 \mathrm{mg} \mathrm{Zn} \mathrm{L}^{-1}$ for $28 \mathrm{~d}$. Note that the lumen-facing surface is almost completely oppilated and irregular. Bar $=200 \mu \mathrm{m}$. (I) The hepatopancreas from a shrimp exposed to $0.6 \mathrm{mg} \mathrm{Zn} \mathrm{L}^{-1}$ for $28 \mathrm{~d}$. Melanization of the epithelial cells has appeared. Bar $=50 \mu \mathrm{m}$. ALU, abnormal lumen; BL, basal lamina; Mel, melanization of cells; REc, ruptured epithelial cells. 
Table 1

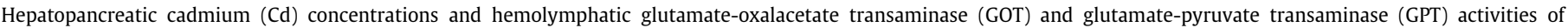
Litopenaeus vannamei exposed to $\mathrm{Cd}$

\begin{tabular}{|c|c|c|c|c|}
\hline \multirow[t]{2}{*}{ Exposure time $(\mathrm{d})$} & \multirow[t]{2}{*}{ Parameter } & \multicolumn{3}{|l|}{ Treatment } \\
\hline & & Control & $\mathrm{Cd} 0.1 \mathrm{mg} \mathrm{L}^{-1}$ & $\overline{C d} 0.2 \mathrm{mg} \mathrm{L}^{-1}$ \\
\hline \multirow[t]{3}{*}{7} & Cd concentration ( $\mathrm{mg} \mathrm{g}^{-1}$ dry weight) & N.D. & $0.07(0.03)^{*}$ & $0.18(0.09)^{*}$ \\
\hline & GOT activity $\left(\mathrm{U} \mathrm{L}^{-1}\right)$ & $23.73(7.00)$ & $\mathrm{N} / \mathrm{A}$ & $42.79(27.30)$ \\
\hline & GPT activity ( $\left.\mathrm{U} \mathrm{L}^{-1}\right)$ & $15.00(4.00)$ & $\mathrm{N} / \mathrm{A}$ & $52.85(31.52)^{*}$ \\
\hline \multirow[t]{3}{*}{14} & Cd concentration ( $\mathrm{mg} \mathrm{g}^{-1}$ dry weight) & N.D. & $0.19(0.08)^{*}$ & $0.37(0.07)^{*}$ \\
\hline & GOT activity $\left(\mathrm{U} \mathrm{L}^{-1}\right)$ & $19.42(3.05)$ & $\mathrm{N} / \mathrm{A}$ & $51.34(24.62)^{*}$ \\
\hline & GPT activity ( $\left.\mathrm{U} \mathrm{L}^{-1}\right)$ & $15.10(3.05)$ & $\mathrm{N} / \mathrm{A}$ & $50.91(35.07)^{*}$ \\
\hline \multirow[t]{3}{*}{21} & Cd concentration ( $\mathrm{mg} \mathrm{g}^{-1}$ dry weight) & N.D. & $0.24(0.06)^{*}$ & $0.38(0.05)^{*}$ \\
\hline & GOT activity $\left(\mathrm{U} \mathrm{L}^{-1}\right)$ & N/A & $\mathrm{N} / \mathrm{A}$ & $\mathrm{N} / \mathrm{A}$ \\
\hline & GPT activity ( $\left.\mathrm{U} \mathrm{L}^{-1}\right)$ & $\mathrm{N} / \mathrm{A}$ & $\mathrm{N} / \mathrm{A}$ & $\mathrm{N} / \mathrm{A}$ \\
\hline \multirow[t]{3}{*}{28} & Cd concentration ( $\mathrm{mg} \mathrm{g}^{-1}$ dry weight) & N.D. & $0.33(0.08)^{*}$ & $0.52(0.18)^{*}$ \\
\hline & GOT activity $\left(\mathrm{U} \mathrm{L}^{-1}\right)$ & $16.18(3.00)$ & $\mathrm{N} / \mathrm{A}$ & $35.38(11.68)^{*}$ \\
\hline & GPT activity ( $\left.\mathrm{U} \mathrm{L}^{-1}\right)$ & $14.38(6.59)$ & $\mathrm{N} / \mathrm{A}$ & $54.80(32.42)^{*}$ \\
\hline
\end{tabular}

N.D., the result of measurement was under detection limit.

$\mathrm{N} / \mathrm{A}$, the data was not available.

Values are expressed as mean (SD) of all measurements.

Mean values of treated groups significantly differ from those of the corresponding control group $(p<0.05)$.

Table 2

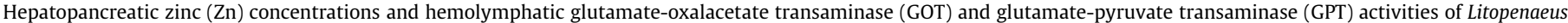
vannamei exposed to $\mathrm{Zn}$

\begin{tabular}{|c|c|c|c|c|}
\hline \multirow[t]{2}{*}{ Exposure time $(\mathrm{d})$} & \multirow[t]{2}{*}{ Parameter } & \multicolumn{3}{|l|}{ Treatment } \\
\hline & & Control & Zn $0.05 \mathrm{mg} \mathrm{L}^{-1}$ & $\mathrm{Zn} 0.2 \mathrm{mg} \mathrm{L}^{-1}$ \\
\hline \multirow[t]{3}{*}{7} & Zn concentration ( $\mathrm{mg} \mathrm{g}^{-1}$ dry weight) & $0.16(0.01)$ & $0.21(0.02)$ & $0.31(0.04)^{*}$ \\
\hline & GOT activity ( $\left.\mathrm{U} \mathrm{L}^{-1}\right)$ & $23.73(7.00)$ & $\mathrm{N} / \mathrm{A}$ & $85.75(27.65)^{*}$ \\
\hline & GPT activity ( $\mathrm{U} \mathrm{L}^{-1}$ ) & $15.00(4.00)$ & $\mathrm{N} / \mathrm{A}$ & $78.20(41.85)^{*}$ \\
\hline \multirow[t]{3}{*}{14} & Zn concentration ( $\mathrm{mg} \mathrm{g}^{-1}$ dry weight) & $0.17(0.01)$ & $0.20(0.02)$ & $0.34(0.05)^{*}$ \\
\hline & GOT activity $\left(\mathrm{U} \mathrm{L}^{-1}\right)$ & $19.42(3.05)$ & $\mathrm{N} / \mathrm{A}$ & $24.16(12.43)$ \\
\hline & GPT activity $\left(\mathrm{U} \mathrm{L}^{-1}\right)$ & $15.10(3.05)$ & $\mathrm{N} / \mathrm{A}$ & $19.85(9.93)$ \\
\hline \multirow[t]{3}{*}{21} & $\mathrm{Zn}$ concentration ( $\mathrm{mg} \mathrm{g}^{-1}$ dry weight) & $0.21(0.02)$ & $0.19(0.02)$ & $0.21(0.01)$ \\
\hline & GOT activity ( $\left.\mathrm{U} \mathrm{L}^{-1}\right)$ & $\mathrm{N} / \mathrm{A}$ & $\mathrm{N} / \mathrm{A}$ & $\mathrm{N} / \mathrm{A}$ \\
\hline & GPT activity $\left(\mathrm{U} \mathrm{L}^{-1}\right)$ & $\mathrm{N} / \mathrm{A}$ & $\mathrm{N} / \mathrm{A}$ & $\mathrm{N} / \mathrm{A}$ \\
\hline \multirow[t]{3}{*}{28} & Zn concentration ( $\mathrm{mg} \mathrm{g}^{-1}$ dry weight) & $0.19(0.04)$ & $0.18(0.01)$ & $0.22(0.04)$ \\
\hline & GOT activity ( $\left.\mathrm{U} \mathrm{L}^{-1}\right)$ & $16.18(3.00)$ & $\mathrm{N} / \mathrm{A}$ & $22.65(4.58)$ \\
\hline & GPT activity (U L ${ }^{-1}$ ) & $14.38(6.59)$ & $\mathrm{N} / \mathrm{A}$ & $29.12(13.73)$ \\
\hline
\end{tabular}

N.D., the result of measurement was under detection limit.

$\mathrm{N} / \mathrm{A}$, the data was not available.

Values are expressed as mean (SD) of all measurements.

Mean values of treated groups significantly differ from those of the corresponding control group $(p<0.05)$.

also examined the effects of pesticides and fungicides on other decapods (Lightner et al., 1996; Bhavan and Geraldine, 2000).

Förlin et al. (1986) and Khangarot (1992) studied the effects of the heavy metals, copper $(\mathrm{Cu})$ and $\mathrm{Cd}$, on ultrastructural changes in the liver of a teleost. Major alterations of liver cells after fish were exposed to $\mathrm{Cu}$ or $\mathrm{Cd}$ included proliferation of smooth endoplasmic reticula (SER), fragmentation and dilation of cisternae of rough endoplasmic reticula (RER), detachment of ribosomes from endoplasmic reticula (ER), hypertrophy of Golgi complexes, swelling of mitochondria with an amorphous, dense and intramaterial deposition, the appearance of a large number of lysosome-like inclusion bodies and autophagic vacuoles, and a tendency towards fibrosis. A related study also examined the effects of hexavalent chromium on the grass shrimp, Palaemonetes pugio (Doughtie and Rao, 1984). Various degrees of nuclear hypertrophy and nuclear inclusions, a relative decrease in mitotic activities within the tubule apices, an obvious loss of intracellular organization, degenerative cytoplasmic changes, and thickening of the basal lamina were observed in hepatopancreatic cells of $P$. pugio treated with hexavalent chromium.

Previous studies reported that, in unpolluted water, the average concentration of $\mathrm{Cd}$ is about $0.05 \mu \mathrm{g} \mathrm{L} \mathrm{L}^{-1}$, while in coastal waters it tends to increase to over $0.1 \mu \mathrm{g} \mathrm{L}^{-1}$ and even over $10 \mu \mathrm{g} \mathrm{L}^{-1}$ in some areas due to anthropogenic input, local geological conditions, and human activities (Soegianto et al., 1999). Likewise, Zn concentrations in coast water had also been detected as $4-800 \mu \mathrm{g} \mathrm{L}^{-1}$ (Bryan, 1976). Hence, the existence of heavy metals in coastal water should be considered when directly using coastal waters for shrimp farming. We had previously reported the acute toxicities of $\mathrm{Zn}$ and $\mathrm{Cd}$ for L. vannamei (Wu and Chen, 2004). The 24-h $\mathrm{LC}_{50}$ values for $L$. vannamei were $3.98 \mathrm{mg} \mathrm{Zn} \mathrm{L}^{-1}$ and $2.58 \mathrm{mg} \mathrm{Cd} \mathrm{L}^{-1}$. In this study, we investigated the structural and biochemical alterations of hepatopancreas of L. vannamei after exposed to sub-lethal concentrations of these two metals. From our studies, structural changes in the hepatopancreas after metal exposure were obvious. Infiltration of hemocytes, separation of necrotic cells from the basal lamina, and the formation of necrotic tubules were observed after L. vannamei was exposed to heavy metals in this study. These symptoms are likely common and typical responses when prawn are exposed to toxicants causing lesions in the hepatopancreas, since the same symptoms were also reported in other prawn species exposed to higher concentrations of aflatoxin, endosulfan, or a fungicide (Lightner et al., 1982; Bautista, 1994; Lightner et al., 1996; Bhavan and Geraldine, 2000). A thickening of the basal lamina was also observed in Macrobrachium malcolmsonii after exposure to endosulfan, and the authors considered 
that it might have been due to production of collagen and walling off by hemocytes and also represented a defensive reaction against the toxicity of xenobiotics (Bhavan and Geraldine, 2000). Among the different types of cells in the tubular epithelia of the hepatopancreas, R-cells have been found to be the most readily and severely affected (Vogt, 1990; Bautista, 1994). R-cells are characterized by numerous vacuoles and lipid droplets appearing within the cytoplasm, and they are considered to be the major lipid reserve in the hepatopancreas. We found that a common feature of the hepatopancreas of $\mathrm{Cd}$ - and $\mathrm{Zn}$-exposed L. vannamei was the appearance of moderate to heavy vacuolization in tubular epithelial cells. Since xylene was used when we stained the tissue paraffin sections with hematoxylin and eosin, it is possible that lipids within the lipid droplets or lipid-containing vacuoles may have been dissolved away, and the resulting tissue section showed only the existence of hollow vacuoles of cells. It was reported in M. malcolmsonii that the number of R-cells in the tubular epithelium of the hepatopancreas of test prawns exposed to $10.6 \mathrm{ng} \mathrm{L}^{-1}$ endosulfan was higher than that of control prawns (Bhavan and Geraldine, 2000). Therefore, the appearance of heavy vacuolization in R-cells might have resulted from an increase in the lipid content of cells and/or an increase in the number of R-cells.

$\mathrm{Zn}$ is a ubiquitous and nutritionally essential element that is required for several normal physiological functions, while $\mathrm{Cd}$ is a non-essential trace metal that exerts its toxic effects on animals. Hence, it is not surprising that $\mathrm{Zn}$ was detected in the hepatopancreas of control L. vannamei, while Cd was not. In our study, both exogenous $\mathrm{Cd}$ and $\mathrm{Zn}$ accumulated in the hepatopancreas of $L$. vannamei after exposure for $14 \mathrm{~d}$. However, these two metals behaved differently after exposure for 21 and $28 \mathrm{~d}$. It had been reported that marine prawns possess the ability to regulate tissue $\mathrm{Zn}$ concentrations for normal physiology (White and Rainbow, 1985; Vijayram and Geraldine, 1996). It was believed that metallothioneins involved in the regulation of essential trace elements (Roesijadi, 1992). Also, we had previously demonstrated that the pattern of matellothionein expressed deeply associated with the distribution of $\mathrm{Zn}$ in the tissues of L. vannamei (Wu and Chen, 2005b). Thus, our histopathological observations from $0.2 \mathrm{mg} \mathrm{Zn} \mathrm{L}^{-1}$-treated shrimp exposed for 14 and $28 \mathrm{~d}$ showed no obvious differences from control shrimp, which can possibly be explained by the declining accumulation of $\mathrm{Zn}$, which might have decreased its hepatopancreatic toxicity.

GOT, also called aspartate aminotransferase (ASAT), catalyzes an important reaction of the molecular rearrangement involving amino acids linked to the citric acid cycle at two points (oxaloacetic and ketoglutaric acids), being the most important mechanism for introducing reduction equivalents into mitochondria (Urich, 1994). GPT, also called alanine aminotransferase (ALAT), predominates in organs with intensive glycogenesis, such as the liver (Urich, 1994; Torre et al., 2000). Serum GOT and GPT are important diagnostic tools in medicine and clinics, and are used to detect the toxic effects of various pollutants (Nelson and Cox, 2000). The effects of heavy metals on serum or liver enzyme activities including GOT and GPT activities of several teleost species have recently been studied (Vaglio and Landriscina, 1999; Torre et al., 2000; Kim and Kang, 2004). After sub-chronic dietary Cu exposure for $40 \mathrm{~d}$, increased serum GOT and GPT concentrations with increasing time and dose were observed in the rockfish, Sebastes schlegeli (Kim and Kang, 2004). In addition, it was also reported in another teleost (Sparus aurata) that Cd exposure may decrease GOT and GPT activities in liver cells (Vaglio and Landriscina, 1999). The authors of those two articles suggested that the liver is rich in GOT and GPT, and damage to it can result in the liberation of large quantities of these enzymes into the blood. Therefore, increases in GOT and GPT activities in the serum of heavy metal-treated fish are assumed to be a result of liver damage by the heavy metals. In fact, related studies on crustacean and prawn species are fairly limited. Galindo-Reyes et al. (2000) studied some enzymatic alterations in L. vannamei exposed to pesticides, including hemolymphatic GOT and GPT activities. However, they found no statistically significant differences in either GOT or GPT activities among treatments and control sets, and concluded that the pesticides assayed had no impact on GOT or GPT activities in shrimp hemolymph. In this study, we found that both hemolymphatic GOT and GPT activities of $L$. vannamei were influenced after exposure to $\mathrm{Cd}$ and $\mathrm{Zn}$. It is very interesting that $\mathrm{Cd}$ and $\mathrm{Zn}$ showed different effects on the hemolymphatic GOT and GPT activities. Unlike $\mathrm{Cd}$, a non-essential and xenobiotic element, $\mathrm{Zn}$ is an essential element for maintaining normal functions of most organisms. Many organisms, such as the prawn species, $M$. malcolmsonii, have been reported to possess the ability to regulate the levels of $\mathrm{Zn}$ entering into and being excreted from the body in order to maintain a stable level within the body when they are exposed to ambient $\mathrm{Zn}$ (Vijayram and Geraldine, 1996). Therefore, the recovery of hemolymphatic GOT and GPT activities was considered to be related to the intrinsic regulation of $\mathrm{Zn}$ by L. vannamei to decrease its toxicity, and shows that the damage to the hepatopancreas caused by exposure to $\mathrm{Zn}$ can be repaired. This was also supported by our histological results from the hepatopancreas of shrimp exposed to $0.2 \mathrm{mg} \mathrm{Zn} \mathrm{L}^{-1}$ for 14 and $28 \mathrm{~d}$, in that the lesions of the hepatopancreas did not worsen and probably began to recover from the damage caused by exposure to a lower concentration of $\mathrm{Zn}$. A concentration of $0.6 \mathrm{Zn} \mathrm{mg} \mathrm{L}{ }^{-1}$ might be so toxic for $L$. vannamei that its recovery mechanism failed, since hepatopancreatic tubules of individuals exposed for $28 \mathrm{~d}$ were seriously atrophied, and the lumina were almost completely oppilated in this study.

Hepatopancreas is not only a digestive organ possesses abilities of absorption, digestion, storage, and secretion, but also a major site where biotransformation and detoxification undergo in crustaceans. In this study, we demonstrated that histological alterations appeared in the hepatopancreas of L. vannamei after long-term exposure to $\mathrm{Cd}$ and $\mathrm{Zn}$, and included vacuolization of epithelial cells, loss of the star shape of the lumen, a thickening of the basal lamina, an increased distance between adjacent tubules, the appearance of a scraggy lumen surface, and infiltration of hemocytes. In addition, atrophy and necrosis of tubules as well as melanization were observed in animals treated at higher doses. GOT and GPT levels were also determined in this study as biochemical evidence to confirm that the hepatopancreas of $L$. vannamei was damaged after exposure to $\mathrm{Cd}$ and $\mathrm{Zn}$. Therefore, results of the present study provided a reasonable explanation for our previous observations ( $\mathrm{Wu}$ and Chen, 2005a), that the structure and functions of hepatopancreas of $L$. vannamei were damaged by $\mathrm{Cd}$ and $\mathrm{Zn}$, resulting in the alterations and unavailability of biochemical and nutritional materials within the hepatopancreas and consequently growth retardation. Also, the influence of heavy metals on the biotransformation ability and efficiency of hepatopancreas to other environmental pollutants should also be considered and will be investigated in the future.

\section{References}

Ahearn, G.A., Mandal, P.K., Mandal, A., 2004. Mechanisms of heavy-metal sequestration and detoxification in crustaceans: a review. J. Comp. Physiol. B 174, 439-452.

Bautista, M.N., Lavilla-Pitogo, C.R., Subosa, P.F., 1994. Aflatoxin B $B_{1}$ contamination of shrimp feeds and its effect on growth and hepatopancreas of pre-adult Penaeus monodon. J. Sci. Food Agric. 65, 5-11.

Bell, T.A., Lightner, D.V., 1988. A Handbook of Normal Penaeid Shrimp Histology. World Aquaculture Society, Baton Rouge, LA.

Bhavan, P.S., Geraldine, P., 2000. Histopathology of the hepatopancreas and gills of the prawn Macrobrachium malcolmsonii exposed to endosulfan. Aquat. Toxicol. 50, 331-339.

Bryan, G.W., 1976. Heavy metal contamination in the sea. In: Johnston, R. (Ed.), Marine Pollution. Academic Press, New York, USA, pp. 185-302. 
1026

J.-P. Wu et al./Chemosphere 73 (2008) 1019-1026

Caceci, T., Neck, K.F., Lewis, D.H., Sis, R.F., 1988. Ultrastructure of the hepatopancreas of the pacific white shrimp, Penaeus vannamei (Crustacea: Decapoda). J. Mar. Biol. Assoc. UK 68, 323-337.

Dall, W., Moriarty, D.J.W., 1983. Functional aspects of nutrition and digestion. In: Mantel, L.H. (Ed.), The Biology of Crustacea. Internal Anatomy and Physiological Regulation, vol. 5. Academic Press, New York, pp. 215-261.

Doughtie, D.G., Rao, K.R., 1984. Histopathological and ultrastructural changes in the antennal gland, midgut, hepatopancreas, and gill of grass shrimp following exposure to hexavalent chromium. J. Inver. Pathol. 43, 89-108.

Förlin, L., Haux, C., Karlsson-Norrgren, L., Runn, P., Larsson, Á., 1986. Biotransformation enzyme activities and histopathology in rainbow trout, Salmo gairdneri, treated with cadmium. Aquat. Toxicol. 8, 51-64.

Galindo-Reyes, J.G., Venezia, L.D., Lazcano-Alvarez, G., Rivas-Mendoza, H., 2000. Enzymatic and osmoregulative alterations in white shrimp Litopenaeus vannamei exposed to pesticides. Chemosphere 40, 233-237.

James, M.O., Boyle, S.M., 1998. Cytochrome P450 in Crustacea. Comp. Biochem. Phys. C 121, 157-172.

Khangarot, B.S., 1992. Copper-induced hepatic ultrastructural alterations in the snake-headed fish, Channa punctatus. Ecotoxicol. Environ. Saf. 23, 82-293.

Kim, S.-G., Kang, J.-C., 2004. Effect of dietary copper exposure on accumulation, growth and hematological parameters of the juvenile rockfish, Sebastes schlegeli. Mar. Environ. Res. 58, 65-82.

Lightner, D.V., Redman, R.M., Price, R.L., Wiseman, M.O., 1982. Histopathology of aflatoxicosis in the marine shrimp Penaeus stylirostris and P. vannamei. J. Inver. Pathol. 40, 279-291.

Lightner, D.V., Hasson, K.W., White, B.L., Redman, R.M., 1996. Chronic toxicity and histopathological studies with Benlate, a commercial grade of benomyl, in Penaeus vannamei (Crustacea: Decapoda). Aquat. Toxicol. 34, 105-118.

Martinez, M., Torreblanca, A., Ramo, J.D., Pastor, A., Diaz-Mayans, J., 1993. Cadmium induced metallothionein in hepatopancreas of Procambarus clarkii: quantification by a silver-saturation method. Comp. Biochem. Phys. C 105, 263-267.

Nelson, D.L., Cox, M.M., 2000. Lehninger Principles of Biochemistry. Worth Publishers, New York. pp. 623-658.
Pederson, S.N., Lundebye, A.-K., Depledge, M.H., 1997. Field application of metallothionein and stress protein biomarkers in the shore crab Carcinus maenas exposed to trace metals. Aquat. Toxicol. 37, 183-200.

Roesijadi, G., 1992. Metallothioneins in metal regulation and toxicity in aquatic animals. Aquat. Toxicol. 22, 81-114.

Snyder, M.J., 2000. Cytochrome P450 enzymes in aquatic invertebrates: recent advances and future directions. Aquat. Toxicol. 48, 529-547.

Söderhäll, K., Smith, V.J., 1983. Separation of the haemocyte populations of Carcinus maenas and other marine decapods, and prophenoloxidase distribution. Dev. Comp. Immunol. 7, 229-239.

Soegianto, A., Charmantier-Daures, M., Trilles, J.-P., Charmantier, G., 1999. Impact of cadmium on the structure of gills and epipodites of the shrimp Penaeus japonicus. Aquat. Living Resour. 12 (1), 57-70.

Torre, F.R., Salibián, A., Ferrari, L., 2000. Biomarkers assessment in juvenile Cyprinus carpio exposed to waterborne cadmium. Environ. Pollut. 109, 277-282.

Urich, K., 1994. Comparative Animal Biochemistry. Springer, Berlin.

Vaglio, A., Landriscina, C., 1999. Change in liver enzyme activity in the teleost Sparus aurata in response to cadmium intoxication. Ecotoxicol. Environ. Saf. 43, 111116.

Vijayram, K., Geraldine, P., 1996. Regulation of essential heavy metals ( $\mathrm{Cu}, \mathrm{Cr}$, and $\mathrm{Zn}$ ) by the freshwater prawn Macrobrachium malcolmsonii. Bull. Environ. Contam. Toxicol. 56, 335-342.

Vogt, G., 1990. Pathology of midgut gland-cells of Penaeus monodon post-larvae after Leucaena leucocephala feeding. Dis. Aquat. Organ. 9, 45-61.

White, S.L., Rainbow, P.S., 1985. On the metabolic requirements for copper and zinc in mollusks and crustaceans. Mar. Environ. Res. 16, 215-229.

Wu, J.P., Chen, H.-C., 2004. Effects of cadmium and zinc on oxygen consumption, ammonium excretion, and osmoregulation of white shrimp (Litopenaeus vannamei). Chemosphere 57, 1591-1598.

Wu, J.-P., Chen, H.-C., 2005a. Effects of cadmium and zinc on the growth, food consumption, and nutritional conditions of the white shrimp, Litopenaeus vannamei (Boone). Bull. Environ. Contam. Toxicol. 74, 234-241.

Wu, J.-P., Chen, H.-C., 2005b. Metallothionein induction and heavy metal accumulation in white shrimp Litopenaeus vannamei exposed to cadmium and zinc. Comp. Biochem. Phys. C 140, 383-394. 